\title{
PERGULATAN SOSIORELIGIUS DI TENGAH ARUS PERUBAHAN EKONOMI PADA MASYARAKAT KAMPUNG INGGRIS PARE KEDIRI
}

\author{
Ahmad Subakir \\ Institut Agama Islam Negeri Kediri, Indonesia \\ E-mail: bakirkediri@gmail.com
}

\begin{abstract}
The establishment of educational institutes which mainly focus on English language course at Kampung Inggris (the Village of English) of Pare-Kediri plays pivotal role in the process of transformation of the local society especially in socio-religious and economic aspects they deal with. This article attempts to reveal socio-religious characteristic of the society at the Kampung Inggris along with their work ethos. The change of economic aspect has led to encounter of socio-religious aspect and the work ethos within the society as a result of the establishment of the English language courses coupled with the advent of outsiders who take the course. Employing socio-economic approach the study scrutinizes the dynamic of socio-religious aspect which grows as a consequence of the economic change. To get the necessary data and information, I use a panel of methods, which comprises interview, observation, and documentation. The discussion will focus on the socio-religious problems faced by the residents of the Kampung Inggris and their work ethos. The study finds that there has been a substantial change among the local society. The agrarian society at the Kampung Inggris has now transformed into capitalistic one. The transformation has subsequently affected their religious pattern from organic-religious to mechanic-religious.
\end{abstract}

Keywords: Kampung Inggris; socio-religious; work ethos; organic-religious; mechanic-religious.

\section{Pendahuluan}

Perubahan masyarakat dari agraris menuju kapitalis memengaruhi lingkungan sekitar, baik secara fisik maupun non-fisik. Pengaruh tersebut paling tidak tercermin dalam guna lahan, kondisi sosial 
ekonomi dan keagamaan masyarakat. ${ }^{1}$ Salah satu pengaruh yang nyata adalah kapitalisasi pendidikan. Aktivitas pendidikan, selain memengaruhi lingkungan sekitar agar lebih maju dalam bidang ilmu pengetahuan dan sumber daya manusia, aktivitas ini juga memicu terbentuknya masyarakat kapitalis baru sesuai arus pasar yang ditimbulkan.

Perubahan yang digambarkan di atas sekiranya dapat dijumpai pada masyarakat di Kampung Inggris Pare Kediri. Kemunculan komunitas Kampung Inggris pada tahun $2001^{2}$ menggiring masyarakat di sana yang semula bercorak agraris lambat laun berubah menjadi kapitalis karena faktor perubahan komoditas ekonomi. ${ }^{3}$ Mayoritas masyarakat yang awalnya adalah petani, peternak, dan buruh berubah menjadi pemodal lembaga-lembaga kursus Bahasa Inggris atau pengusaha tempat-tempat kos yang lebih menjanjikan keuntungan ekonomi yang besar. Banyak pula penduduk yang kemudian beralih profesi menjadi pedagang atau penyedia jasa seiring semakin ramainya pendatang dari luar daerah yang datang untuk menempuh kursus Bahasa Inggris di tempat tersebut. Alih profesi ini mereka lakukan dengan dalih untuk memenuhi kebutuhan keseharian para pendatang di Kampung Inggris.

Keberadaan lembaga kursus Bahasa Inggris di Pare Kediri berdasarkan dokumen tertulis sudah ada sejak tahun 1977. Hingga penelitian ini dilakukan, jumlah lembaga kursus Bahasa Inggris di Kampung Inggris ini tidak kurang dari 171 lembaga kursus. Dalam setahun, lembaga-lembaga tersebut dapat menampung lebih dari 4.000

1 Roland Robertson, Agama: Dalam Analisa dan Interpretasi Sosiologi, terj. Achmad Fedyani Saifuddin (Jakarta: Rajawali, 1988), 113.

${ }^{2}$ Ery Supriyadi R., Peran Universitas dalam Pengembangan Ekonomi Lokal: Kasus Kawasan Pendidikan Tinggi Jatinangor (Bandung: t.tp., 2012), 202.

${ }^{3}$ Masyarakat agraris menggantungkan ekonominya pada produksi dan pemeliharaan tanaman dan tanah pertanian. Cara lain untuk mendefinisikan masyarakat agraris ialah dengan melihat besarnya produksi total budaya pertanian suatu bangsa. Soerjono Soekamto, Pengantar Kesejabteraan Sosial (Jakarta: Gramedia, 2000), xxi. Sedangkan masyarakat Kapitalis menggantungkan ekonominya pada modal capital untuk menggerakkan perekonomian dalam memproduksi komoditas. Dalam perekonomian kapitalis, setiap masyarakat dapat mengatur nasibnya sendiri sesuai dengan kemampuannya. Semua orang bebas bersaing dalam bisnis untuk memeroleh laba sebesar-besarnya. Semua orang bebas malakukan kompetisi untuk memenangkan persaingan bebas dengan berbagai cara. Mubyarto, Reformasi Sistem Ekonomi: Dari Kapitalisme menuju Ekonomi Kerakyatan (Jakarta: Aditya Media, 1999), 25. 
siswa. ${ }^{4}$ Aktivitas kursus Bahasa Inggris tersebut bisa saja berpengaruh terhadap kehidupan sosial, keagamaan dan ekonomi masyarakat setempat. Fenomena ini tentu menarik untuk diteliti guna mendapatkan gambaran yang komprehensif tentang karakteristik Sosioreligius dan etos kerja masyarakat di Kampung Inggris. Dugaan awal penelitian ini, bahwa perubahan yang terjadi dalam bidang ekonomi karena aktivitas lembaga kursus di tempat tersebut menyebabkan terjadinya pergulatan Sosioreligius dan etos kerja pada warga setempat, sehingga berdampak terhadap transformasi dari masyarakat agraris menuju masyarakat kapitalis.

Setelah melakukan pelacakan terhadap tema terkait, belum ada kajian yang secara spesifik membahas topik yang akan didalami dalam artikel ini. Memang ada beberapa penelitian yang sudah membahas tentang Kampung Inggris, namun belum ada kajian yang mengfokuskan pada kondisi Sosioreligius dan etos kerja masyarakat di Kampung Inggris. Desika Putri Mardiani yang melakukan penelitian di Kampung Inggris, hanya membidik korelasi antara partisipasi masyarakat dengan terciptanya sistem pendidikan berbasis masyarakat. Penelitian terkait sejarah perekonomian Kampung Inggris pun pernah dilakukan. Namun penelitian tersebut tidak mendalami aspek Sosioreligius akibat perkembangan ekonomi di Kampung Inggris. Menurut penjelasan dari beberapa penelitian sebelumnya, bahwa perkembangan Desa Tulungrejo menjadi Kampung Inggris tidak terlepas dari sosok bernama Yazid, yang pernah menjadi pemandu Clliford Geertz ketika menyusun buku The Religion of Java. Awalnya, ia ingin memasyarakatkan Bahasa Inggris untuk kepentingan dakwah. Di kemudian hari, Desa Tulungrejo semakin popular sebagai destinasi kursus Bahasa Inggris, sehingga mendapat julukan "Kampung Inggris".

Kajian tentang hubungan agama dan ekonomi memang bukan topik baru dalam kajian akademik. Umumnya, kajian-kajian dalam topik ini merujuk pada tesis Max Weber tentang kemajuan masyarakat Eropa di awal abad ke-20. Menurut Weber, kemajuan ekonomi Barat mempunyai hubungan langsung dengan spirit keagamaan yang dianut masyarakat Eropa. Semangat kebangkitan ekonomi tersebut lahir dari watak disiplin dan perilaku kaum pengusaha progresif yang umumnya adalah penganut Protestan yang taat. Untuk konteks masyarakat Muslim, relasi agama dan ekonomi pernah disebut oleh Clifford

\footnotetext{
${ }^{4}$ Sumber data: Pusat informasi Kampung Inggris Pare tahun 2017.
} 
Geertz yang menemukan banyak pengusaha di Kediri adalah anggota organisasi Islam Modernis. Mereka ini merupakan kelompok santri yang sangat taat menjalankan ibadah; memiliki tingkat kedisiplinan yang tinggi; senantiasa bekerja keras; dan berhemat atau jauh dari perilaku konsumtif.

\section{Gambaran Umum Kampung Inggris}

Kampung Inggris merupakan sebutan untuk Dusun Singgahan ${ }^{5}$ Desa Tulungrejo dan Desa Pelem Kecamatan Pare Kabupaten Kediri. Dua desa ini menjadi sentra aktivitas kursus Bahasa Inggris. Julukan Kampung Inggris konon berasal dari wartawan yang pernah meliput aktivitas kursus Bahasa Inggris di wilayah tersebut. Kehadiran Kampung Inggris sangat lekat dengan sosok Yazid dan Kalend. Yazid seorang ustaz yang menguasai delapan bahasa dunia. Ia termotivasi untuk berdakwah melalui Bahasa Inggris setelah beradu pendapat dengan antropolog Amerika Serikat, Cliford Geertz, pada tahun 1950an. Niat itu kemudian direalisasikan oleh santrinya, Kalend melalui kegiatan belajar mengajar Bahasa Inggris.

Secara geografis, Desa Tulungrejo dan Desa Pelem dekat dengan Kecamatan Pare. Lahan desa yang belum terbangun seluas 662,366 Ha pada tahun 2008. Sementara luas lahan pertaniannya mencapai 586,34 Ha. Fungsi lahan didominasi oleh pertanian. Sedangkan pola guna lahannya cenderung linear sepanjang jalan utama. Sedangkan fungsi bangunan pemukiman terbesar adalah untuk perdagangan dan jasa, jumlahnya masing-masing 549 dan 197 unit. $^{6}$

Terkait organisasi masyarakat, di Desa Tulungrejo dan Desa Pelem terdapat 11 organisasi. Masing-masing organisasi memiliki struktur yang jelas, terdapat pembagian wewenang antara pengurus dan anggota. Kegiatan-kegiatan dalam organisasi sesuai dengan tujuan pembentukan organisasi bersangkutan. Keberadaan wadah sosial dan keagamaan bagi masyarakat di sana sudah ada sebelum Kampung Inggris terbentuk, kecuali perkumpulan pemilik kos. Organisasi masyarakat yang memiliki jumlah partisan terbesar di Kampung

\footnotetext{
5 Nama Singgahan dalam bahasa jawa disebut panglerenan yang berarti tempat singgah bagi orang yang melakukan perjalanan. Pada masa kerajaan Majapahit, masyarakat yang berlalu-lalang biasanya beristirahat di tempat tersebut, waktu itu masih berupa hutan. Mayoritas masyarakat yang menempatinya berasal dari Kudus. Karena sering dijadikan tempat singgah, akhirnya dinamai Singgahan. Miswanto (Kepala Dusun Singgahan), Wawancara, 1 Maret 2017.

${ }^{6}$ Sumber data: Pusat Informasi Kampung Inggris tahun 2015.
} 
Inggris adalah Jamiyah Nahdlatul Ulama (NU). Sedangkan organisasi yang memiliki jumlah partisan yang paling sedikit adalah Perkumpulan Pengusaha Pembibitan Ikan Mina Jaya. ${ }^{7}$

Kegiatan kemasyarakatan di Kampung Inggris sendiri bisa dibilang cukup padat dan intens seperti ronda, kerja bakti, rapat RT/RW, tablilan, upacara adat, arisan, iuran kematian, istighäthah, dan sebagainya. Semua masyarakat ikut berpartisipasi, meskipun intensitas kegiatannya berbeda-beda antar RT/RW. Di Desa Tulungrejo, sebagian RT masih mengadakan ronda, sementara di Desa Pelem sudah tidak diadakan. Tingkat partisipasi penduduk asli maupun pendatang dalam setiap kegiatan masih tergolong tinggi. Ini menunjukkan bahwa masyarakat masih memegang teguh adat istiadat. $^{8}$

Mayoritas penduduk bekerja di bidang pertanian, jumlahnya mencapai 5693 jiwa. Sedangkan yang dekat dengan pusat Kecamatan Pare, lebih banyak bekerja di bidang perdagangan, perkantoran dan sektor-sektor lain. Desa Tulungrejo dan Desa Pelem tergolong desa swakarya. Meskipun mata pencaharian penduduk mulai beralih menuju non pertanian, ${ }^{9}$ sistem ekonomi berubah menjadi kapitalis, namun masyarakat di sana masih memegang teguh adat istiadat. Kondisi perekonomian di tempat ini bisa disebut mulai masuk fase prakapitalis, karena ekonomi tradisional tidak dapat dipertahankan seutuhnya. ${ }^{10}$

Sejak tahun 1977 di Kecamatan Pare sudah terdapat lembaga kursus yang bernama BEC (Basic English Course). Namun, baru di tahun 2001 muncul sebutan Kampung Inggris yang mencitrakan keberadaan lembaga-lembaga kursus lain yang semakin banyak. Sejak saat itu, jumlah lembaga kursus terus mengalami peningkatan pesat. ${ }^{11}$ Hingga tahun 2016 tercatat ada 171 lembaga. Jumlah siswa yang menempuh pendidikan Bahasa Inggris pun terus meningkat pada tiap tahunnya hingga menembus angka 4500 jiwa di tahun 2015.

\footnotetext{
${ }^{7}$ Sumber data: Pusat Informasi Kampung Inggris tahun 2015.

${ }^{8}$ Sumber data: Pusat Informasi Kampung Inggris tahun 2015.

9 Di Dusun Singgahan sejumlah 740 warga memiliki tingkat pendapatan antara 1.000.000-2.000.000; 400 warga berpendapatan antara 2.000.000; 354 warga berpendapatan sekitar 500.000; dan 672 warga berpendapatan antara 500.0001.000.000. Sumber: Tingkat penghasilan penduduk Dusun Singgahan tahun 2014.

${ }^{10}$ Sumber data: Pusat Informasi Kampung Inggris tahun 2017.

${ }^{11}$ Sumber data: Pusat informasi Kampung Inggris tahun 2017.
} 


\section{Kondisi Sosioreligius Masyarakat di Tengah Arus Perubahan Ekonomi}

Keberadaan lembaga kursus menjadi jembatan transformasi bagi masyarakat di Kampung Inggris. Dengan beralih sebutan menjadi Kampung Inggris, masyarakat di Desa Tulungrejo dan Dempet merasakan adanya perubahan dalam aspek kehidupan seperti perubahan pemikiran (mind set), ekonomi, gaya hidup (life style), dan pendidikan atau pengetahuan. Perubahan tersebut dilatarbelakangi oleh aktivitas lembaga-lembaga kursus dan para siswa yang datang dari berbagai daerah. Situasi ini kemudian menuntut masyarakat setempat agar lebih terbuka dan berpikiran maju. Secara teori, perubahan sosial pada suatu masyarakat berdampak pada kondisi lingkungan di mana masyarakat tadi menetap yang dipengaruhi oleh berbagai hal baru yang muncul. Terkadang proses perubahan itu berlangsung sangat cepat, sehingga kurang disadari. Lembaga kursus dan pendatang menjadi faktor pemicu timbulnya perubahan pada masyarakat di Kampung Inggris dalam beberapa aspek kehidupan mereka.

Salah satu perubahan sosial yang dialami oleh masyarakat di Kampung Inggris ialah pekerjaan. Setelah wawancara dengan warga, peneliti berhasil mengumpulkan data-data terkait perubahan ekonomi di Kampung Inggris. Berdasarkan penjelasan dari warga setidaknya dalam kurun waktu sekitar 30 tahun, terjadi peralihan dari profesi masyarakat yang semula adalah petani, kini berubah mejadi pelaku usaha dan penyedia jasa, sehingga pekerjaan masyarakat di Kampung Inggris bisa dibilang sangat variatif seiring perkembangan ekonomi di tempat tersebut

"Tiga puluh tahun lalu, mayoritas penduduk desa Tulungrejo dan Pelem adalah petani, apalagi Kampung Inggris belum ada. Kampung Inggris baru ada tahun 1970-an, jumlahnya masih belum banyak. Hanya BEC dan Ahmad Yazid Center saja yang ada. Kalau sekarang sudah banyak lembaga kursus Bahasa Inggris dan menyebabkan pekerjaan masyarakat menjadi bermacam-macam". ${ }^{12}$ "Dulu, mayoritas warga adalah petani tapi sekarang sudah bermacam-macam. Sekarang banyak yang menjadi guru, tapi ratarata mereka adalah pendatang semua. Yang dulu petani sekarang juga masih banyak yang bertani, apalagi yang masih memiliki sawah. Sedangkan yang tidak punya sawah, buruh tani, ada yang beralih menjadi tukang, pedagang, pemilik kos-kosan atau pemilik lahan

\footnotetext{
12 Wagiran, Wawancara, Pare 20 Agustus 2017.
} 
untuk lembaga kursus. Sekarang, selain menjadi petani, mayoritas warga Kampung Inggris berwirausaha. Hal ini dibuktikan dengan banyaknya pertokoan, tempat kos dan warung yang ada di Kampung Inggris". ${ }^{13}$

Dari segi ekonomi, mata pencaharian masyarakat sudah tidak lagi terpusat pada sektor pertanian. Setelah keberadaan lembaga-lembaga kursus dan pendatang semakin banyak, kondisi ini mengakibatkan pergeseran mata pencaharian warga di Kampung Inggris. Peluang usaha bagi warga setempat semakin terbuka dalam bidang jasa dan perdagangan. Bagi warga yang memiliki modal besar dan lahan yang luas mereka mulai berinvestasi dengan membuka lembaga kursus baru, tempat kos, dan tempat-tempat usaha lain. Pergeseran mata pencaharian ini tentu berimbas pada pemanfaatan lahan di Kampung Inggris. Dalam kurun 10 tahun terakhir, tercatat 96,55\% fungsi lahan pertanian mengalami deficit. Sebanyak 37,14\% lahan yang mengalami alih fungsi itu telah didirikan bangunan seperti pemukiman, tempat kursus, kos, kios, warung dan sebagainya. Keberadaan lembaga kursus menyumbang perubahan fungsi lahan sebesar $9,6 \%$ setiap tahunnya. ${ }^{14}$

Berdasarkan observasi, perubahan fungsi lahan yang tidak terkendali di Kampung Inggris justru berdampak negatif terhadap aktivitas lain seperti terganggunya lalu lintas di sepanjang Jalan Veteran, Jalan Wahidin, dan Jalan Brawijaya yang merupakan rute angkutan umum Kediri-Surabaya melalui Pare. Untuk menghindari hal tersebut, organisasi-organisasi sosial yang ada seharusnya berperan secara optimal untuk mengatasi persoalan-persoalan yang timbul akibat pengalihan fungsi lahan yang berdampak negatif bagi lingkungan setempat termasuk kelancaran lalu lintas. Cara ini dapat memberikan sugesti positif sehingga masyarakat dapat mengidentifikasi ulang perubahan fungsi lahan dan dampaknya bagi lingkungan.

Perubahan lain yang teridentifikasi adalah pola pikir masyarakat yang semakin terbuka menerima keberadaan orang dari luar daerah yang justru membuka peluang-peluang baru yang bernilai ekonomi. Keterbukaan inilah yang menuntun masyarakat di Kampung Inggris memanfaatkan segala peluang yang tercipta dari keberadaan lembaga kursus dan pendatang di tempaat tersebut, sehingga hal itu

${ }^{13}$ Romlah, Wawancara, Pare 21 Juli 2017.

${ }^{14}$ Ar Rahman Taufik Hidayat, "Pengaruh Keberadaan Kampung Inggris", 6. 
menunjukkan perubahan pola pikir yang semakin maju dan berkembang. Salah seorang warga Kampung Inggris menuturkan.

"Sekarang, masyarakat sudah berpikir maju, tidak seperti dulu.

Dengan semakin banyaknya orang yang masuk kampung, masyarakat menjadi berpikiran maju dan berkembang. Yang dahulu punya tanah tidak terpakai, kini mulai mengumpulkan modal—baik pinjam bank maupun cari investor-untuk membangun lembaga kursus, tempat kos maupun usaha lainnya". ${ }^{15}$

Perubahan pola pikir masyarakat di Kampung Inggris memicu perubahan ekonomi yang cukup besar. Usaha-usaha baru bermunculan seperti lembaga kursus, tempat kos, kios makanan dan minuman, laundry, rental sepeda, warnet, toko kebutuhan sehari-hari, toko pakaian, dan seterusnya. Dampak dari peluang ekonomi yang besar di Kampung Inggris ini menurut Camat Pare ikut mengurangi jumlah pengganguran, tingkat urbanisasi dan transmigrasi, karena warga sudah berpikir untuk memanfaatkan sebaik-baiknya peluangpeluang ekonomi yang muncul akibat keberadaan lembaga kursus dan para pendatang yang sedang menempuh pendidikan. ${ }^{16}$ Warga yang sebelumnya berstatus pengganguran atau ibu rumah tangga kini dapat berjualan makanan, minuman, serta kebutuhan sehari-hari bagi para pendatang di Kampung Inggris. Bahkan peluang ekonomi itu tidak hanya dimanfaatkan warga setempat saja tapi juga pendatang dari luar Kecamatan Pare. ${ }^{17}$

Semakin beragamnya mata pencaharian warga di Kampung Inggris, sebagian warga mulai menangkap peluang yang berbeda, seperti membuka tempat penyewaan sepeda. Karena banyak yang berasal dari lain daerah, sepeda menjadi alat transportasi pilihan para pendatang yang sedang menempuh kursus. Dengan usaha rental sepeda, warga Dusun Singgahan tidak perlu jauh-jauh bekerja di luar. Dengan biaya yang cukup murah, 50.000-70.000 rupiah/bulan tergantung kondisinya dan hanya menyerahkan KTP sebagai jaminan, membuat rental sepeda ini banyak digemari para pendatang. Usaha rental sepeda milik Amrullah misalnya, telah memiliki sekitar 200 unit sepada dengan berbagai model. Amrullah yang awalnya hanya seorang kuli batu, kini menjadi pemilik rental sepeda terbesar di Kampung Inggris yang setiap musim liburan selalu habis disewa. ${ }^{18}$

15 Asmo John, Wawancara, Pare 22 Juli 2017.

16 Ani Wuryani, Wawancara, Pare 20 Juli 2017

${ }^{17}$ Karti, Wawancara, Pare 20 Juli 2017

18 Amrullah, Wawancara, Pare 27 Juli 2017. 
Perubahan ekonomi di Kampung Inggris, menurut masyarakat setempat diyakini sesuai dengan tuntunan ajaran Islam. Tokoh sekaligus pelopor keberadaan Kampung Inggris, Pak Kalend mengungkapkan bahwa bekerja itu ibadah dan harga diri seorang manusia. Ajaran Islam tentang etos kerja juga sangat luar biasa, sebagaimana yang telah diteladankan oleh Rasulullah sendiri. Sudah maklum ketika Rasulullah masih remaja, beliau pernah menjadi pengembala dan pedagang. Beliau berdagang sampai ke Syam, Syiria. Berkat kerja kerasnya, usaha dagang Rasulullah berkembang. Bahkan ketika resmi diangkat sebagai Rasul, semangat kerja Nabi Muhammad tidak kendor. Berbagai urusan dunia dari pemerintahan, ekonomi sampai membuat benteng untuk strategi militer tetap dikerjakan. ${ }^{19}$ Amrullah juga menyatakan hal senada, "sebagai umat Islam yang beriman, kerja harus dipahami sebagai salah satu bentuk ibadah dan harus dilakukan semaksimalnya. Harapannya, pekerjaan tersebut mampu mengembangkan perekonomian dan menciptakan kesejahteraan". ${ }^{20}$

Masyarakat merasa mendapatkan rejeki yang begitu besar dengan keberadaan Kampung Inggris, sehingga kehidupan yang mereka jalani jauh lebih terjamin dibandingkan dua dekade sebelumnya. Selain itu, keberadaan BEC menambah suasana Kampung Inggris semakin religius. Amrullah menggambarkan bahwa Kampung Inggris sekarang seperti kota santri, karena BEC menggunakan pendidikan ala pesantren yang dimodifikasi untuk belajar Bahasa Inggris. Dampaknya, murid-murid yang lulus dari BEC membuat suasana di Pare lebih religius. ${ }^{21}$ Perasaan yang sama juga diungkapkan oleh penduduk asli seperti Karti. Menurutnya, kondisi sekarang jauh lebih islami dibandingkan tahun 90-an (1990-2009). Sekarang banyak kegiatan keagamaan seperti istighäthah, yasinan dan sholawatan yang bukan hanya dilaksanakan oleh warga, tetapi juga pendatang yang sedang belajar Bahasa Inggris. ${ }^{22}$

Pola keberagamaan masyarakat Kampung Inggris kini berbeda dari pola sebelum tahun 2009. Menurut Matsudi, dahulu apabila masyarakat ingin menghadiri tablilan, sholawatan, dan acara-acara lain tidak perlu memakai undangan, cukup diumumkan di masjid atau

\footnotetext{
${ }^{19}$ Kalend Oseng (Pendiri BEC Pare), Wawancara, Pare 20 Juli 2017

${ }^{20}$ Amrullah, Wawancara, Pare 20 Juli 2017

${ }^{21}$ Amrullah, Wawancara, Pare 22 Juli 2017

${ }^{22}$ Karti, Wawancara, Pare 20 Juli 2017
} 
disamapikan oleh Ketua RT. Tetapi sekarang mereka harus diundang dahulu agar hadir. Apalagi pemilik lembaga kursus yang bukan penduduk asli, mereka harus diundang jauh-jauh hari agar bisa hadir. ${ }^{23}$ Ali Sukron juga menyatakan bahwa masyarakat sekarang tidak begitu saja tunduk kepada nasihat kiai atau sesepuh. Mereka harus didudukkan dalam tingkat yang setara. Bahkan untuk melakukan peraturan-peraturan yang sifatnya keagamaan maupun sosial juga harus dibuatkan hukum tertulis. ${ }^{24}$

Dari paparan di atas, dapat disimpulkan bahwa perubahan masyarakat Kampung Inggris yang semula bercorak agraris menjadi kapitalis, merubah pola keberagamaan mereka menjadi mekanisreligius. Maksudnya, masyarakat Kampung Inggris memiliki kesadaran keberagamaan bukan karena ketergantungan akan kebutuhan ekonomi, perlindungan dan kepemimpinan, tetapi struktur masyarakat yang berubah, yang disebabakan oleh perubahan struktur ekonomi mereka. Pola hubungan yang mereka ciptakan dalam aspek sosial keagamaan pun bergeser, dari kebutuhan menjadi keharusan untuk melakukan interaksi. Hal ini disebabkan oleh struktur sosial yang memaksa mereka melakukannya.

Sebagaimana masyarakat Indonesia pada umumnya, masyarakat Kampung Inggris sangat dinamis, terlebih kegiatan ekonominya. Dalam kurun waktu kurang dari 30 tahun, masyarakat Kampung Inggris yang semula agraris berubah menjadi kapitalis. Menurut Ridwan Lubis, ini merupakan dampak dari globalisasi yang tidak bisa dihindari oleh masyarakat secaa umum, termasuk masyarakat di Kampung Inggris. ${ }^{25}$ Tanda-tanda ke arah itu ialah beralihnya profesi masyarakat dari petani dan buruh tani menjadi pengusaha, serta semakin sempitnya lahan pertanian.

Kapitalisasi pendidikan di Kampung Inggris banyak menyerap tenaga kerja. Para pendatang membutuhkan tempat tinggal dan lembaga kursus membutuhkan ruang kelas yang mengakibatkan lahan pertanian semakin berkurang. ${ }^{26}$ Akhirnya, para petani yang hidup di Kampung Inggris mulai beralih profesi apalagi yang memiliki lahan yang luas dan kemampuan modal. Mereka akan membuat tempat kos atau berinvestasi mendirikan lembaga kurus baru yang mungkin saja

\footnotetext{
${ }^{23}$ Matsudi (Perangkat Desa Tulungrejo), Wawancara, Pare 2 Agustus 2017

24 Ali Sukron (Kepala Desa Pelem), Wawancara, Pare 10 Agustus 2017.

25 M. Ridwan Lubis, Agama dan Pembangunan Negara (Jakarta: Badan Litbang dan Diklat Kementerian Agama RI, 2015), 133.

${ }^{26}$ Ali Sukron, Wawancara, Pare 21 Juli 2017.
} 
modalnya dari hasil jual sawah. Sementara buruh-buruh tani memilih beralih profesi sebagai pedagang atau penyedia jasa lain yang dibutuhkan oleh para pendatang di Kampung Inggris. Di samping itu, regenerasi petani juga mengalami penurunan karena 90\% anak muda usia produktif (15-23 tahun) lebih tertarik membuka usaha sendiri atau meneruskan usaha rintisan orang tuanya. ${ }^{27}$

Alih profesi masyarakat di Kampung Inggris terjadi sebagai respons terhadap perubahan sosial yang sedang terjadi. Perubahan sosial di sini adalah suatu proses atau tahapan yang melekat seiring perkembangan suatu masyarakat yang semakin maju, sehingga perlu pemaknaan dan pemahaman yang jelas. ${ }^{28}$ Pola pikir masyarakat di Kampung Inggris yang mengalami perubahan dan perkembangan, melahirkan ide dan inisiatif baru untuk memanfaatkan peluang yang ada. ${ }^{29}$ Masyarakat menjadikan lahan miliknya sebagai komoditas kapital untuk mendapatkan keuntungan. ${ }^{30}$ Mereka mendirikan

27 Observasi Kampung Inggris, 12 Agustus 2017.

28 Perubahan yang terjadi bukanlah bentuk kemunduran, melainkan perubahan kehidupan ekonomi, politik dan sosial keagamaan masyarakat ke arah yang lebih baik. Dengan demikian, perubahan ini merupakan keniscayaan yang harus terjadi. Karena bagaimanapun, aspek ekonomi, politik dan sosial keagamaan adalah hal yang sangat dalam kehidupan masyarakat. Frederick Harbison dan Charles A. Myers, Manpower and Education: Country Studies in Economic Development (New York: McGrawHill Book Company, 1965), x-xi.

29 Etos kerja masyarakat Kampung Inggris dimulai dengan kesadaran akan pentingnya arti tanggung jawab bertahan hidup di masa depan, sebagaimana yang diajarkan agama Islam. Meskipun akiabat dari etos kerja itu terjadinya penyempitan lahan pertanian karena tergantikan oleh peluang usaha-usaha baru yang lebih menjanjikan secara ekonomi. Etos kerja itu semakin menguat ketika didasari oleh keyakinan agama agar setiap muslim agar bekerja untuk keperluan ibadah dan menyejahterakan keluarga. Menurut Max Weber, ajaran agama bisa berpengaruh sangat kuat terhadap sistem-sistem nilai yang ada dalam kebudayaan masyarakat yang bersangkutan. Dalam keadaan demikian, secara langsung atau tidak, etos yang menjadi pedoman dari eksistensi dan kegiatan berbagai pranata yang ada dalam masyarakat (keluarga, ekonomi, politik, dan sebagainya), dipengaruhi, digerakkan, dan diarahkan oleh berbagai sistem nilai yang bersumber dari agama yang dianutnya. Max Weber, Etika Protestan dan Semangat Kapitalisme (Yogyakarta: Narasi Pustaka Promethea, 2015), 65-66.

30 Pada umumnya, masyarakat masih sering melihat pekerjaan sebagai kewajiban atau kebutuhan, belum ada nilai lebih. Implikasinya, semangat kerjanya lemah, cenderung spontan dan tidak berkelanjutan yang mengakibatkan munculnya kelemahan-kelemahan kolektif dalam masyarakat sehingga tidak dapat berinovasi, berkreasi dan berimajinasi. Hal ini timbul akibat lemahnya daya saing dan posisi tawar masyarakat. Hal-hal negatif semcam ini tidak terlihat dari etos kerja Masyarakat Kampung Inggris. 
lembaga kursus, tempat kos, jasa laundry, warung makan dan usahausaha lain yang dibutuhkan pendatang.

Dalam pandangan Karl Marx, bahwa manusia menentukan sejarahnya sendiri. Meskipun dalam prosesnya, ia harus memaksakan diri melawan kodratnya. Sepanjang sejarah, manusia banyak mengubah alam agar lebih berguna bagi tujuannya, meskipun dalam prosesnya ia harus mengubah dirinya sendiri. ${ }^{31}$ Dalam konteks Kampung Inggris, warga juga telah mengubah dan memanfaatkan alam sekitar untuk menggapai keinginannya. Tanpa disadari, perubahan fisik tersebut juga mengubah nilai-nilai keagamaan akibat pertukaran nilai dan norma yang dibawa oleh para pendatang yang belajar dan berinvestasi di Kampung Inggris.

Pemikiran yang umum di kalangan masyarakat Pare terhadap perubahan lahan persawahan juga didasari asas manfaat. Sebab dalam pikiran warga sawah hanya dapat menguntungkan pemiliknya saja. Kalaupun memiliki pekerja, juga terbatas. Berbeda dari lembaga kursus yang dapat menyerap ribuan tenaga kerja sehingga mampu meningkatkan kesejahteraan hidup ribuan orang. Tenaga kerjanya juga tidak terbatas dalam lembaga tersebut, namun juga di luar lembaga seperti warung makan, tempat laundry, travel, camp Bahasa Inggris dan tempat-tempat kos. ${ }^{32}$

Sesuai temuan peneliti di lapangan, masyarakat Kampung Inggris menjadi penentu dirinya sendiri dalam kehidupan. Ketika menghendaki sesuatu, mereka berusaha mewujudkannya sendiri. Karena tanpa diiringi usaha, keinginan hanya akan menjadi anganangan. Masyarakat Kampung Inggris menyadari bahwa kebutuhan hidup mereka semakin hari semakin bertambah dan sebisa mungkin ingin mencukupinya. Dari keinginan mereka untuk menjadikan hidup lebih baik, timbul ide-ide untuk mewujudkannya. Di antara ide tersebut adalah menambah dan beralih pekerjaan. ${ }^{33}$ Karena mengejar

\footnotetext{
31 Margaret M. Poloma, Sosiologi Kontemporer (Jakarta: Rajawali Pers bekerja sama dengan Yayasan Solidaritas Gadjah Mada, 1992), 233.

32 Bandingkan: T.A.M. Tilaar, "Peran Perguruan Tinggi di Daerah Dalam Otonomi Daerah", dalam Pendidikan Untuk Masyarakat Indonesia Baru: 70 Tahun Prof. Dr. H.A.R. Tilaar, M.Sc. (Jakarta: Grasindo, 2002), 223.

${ }^{33}$ Dalam konsepsi Marx, perubahan sosial termasuk agama ada pada kondisi historis yang melekat pada perilaku manusia. Lebih tepatnya pada sejarah kehidupan material manusia karena pada hakikatnya perubahan sosial dapat diterangkan dari sejumlah hubungan sosial yang berasal dari pemilikan modal atau material. Hotman M. Siahaan, Pengantar ke Arah Sejarah dan Teori Sosiologi (Jakarta: Erlangga, 1986), 195.
} 
kebutuhan materi, nilai-nilai organik keagamaan masyarakat Kampung Inggris terlupakan dan mengalami regresi. Akhirnya, praktik-praktik keagamaan semakin luntur, bahkan punah. Namun, masih ada katalisator yang tersisa yaitu melalui kegiatan pengajian rutin.

Dalam konsep historical materialism, perilaku manusia ditentukan oleh kedudukan materinya, dan ide merupakan bagian dari materi itu. Dalam konsep ini, keberadaan struktur ekonomi merupakan awal semua kegiatan manusia. Struktur ekonomi menjadi penggerak perubahan, termasuk proses perubahan sosial keagamaan. ${ }^{34}$ Pada kasus masyarakat Kampung Inggris, semula kesadaran keagamaan yang lahir karena kebutuhan bermasyarakat sebagai bentuk ketergantungan pada lingkungan sosial yang bisa melindungi dan membimbing kehidupan yang diikat oleh norma-norma keagamaan secara tradisional. Kesadaran tersebut lahir karena corak agraris yang tidak mungkin dijalani secara individualis. Namun, lambat laun kesadaran itu berubah karena struktur masyarakat yang berubah akibat perubahan struktur ekonomi. Pola hubungan sosial keagamaan pun bergeser dari kebutuhan menjadi keharusan untuk berinteraksi. Penyebabnya adalah struktur sosial yang memaksa.

\section{Persinggungan Sosioreligius dengan Etos Kerja Masyarakat}

Perubahan masyarakat agraris menuju kapitalis di Kampung Inggris menimbulkan dampak dualistik bagi masyarakat; positif dan negatif. Dampak itu terlihat jelas terutama dalam bidang sosial keagamaan. Rasionalisasi keagamaan akibat perubahan lingkungan fisik maupun non-fisik mulai memengaruhi corak berpikir dan interaksi masyarakat. ${ }^{35}$ Untuk mendalami proses dan tahapan sosial menuju suatu perubahan ini, perlu mengetahui bagaimana proses perubahan sosial itu berlangsung.

Terkait Kampung Inggris, mengetahui latar belakang terbentuknya lembaga kursus dapat menjadi perantara untuk mengetahui tahapan perubahan yang terjadi. Tealah diketahui umum, lembaga kursus pertama yang ada di Dusun Singgahan adalah BEC yang didirikan oleh Pak Kalend pada tanggal 15 Juni 1977. Ia berasal dari Kutai,

${ }^{34}$ Gunter W. Remmling and Robert B. Campbell, Basic Sociology: an Introduction to the Study of Society (New Jersey: Littlefield, Adams dan Co, 1976), 163; Save M. Dagun, Sosio Ekonomi Analisis: Eksistensi Kapitalisme dan Sosialisme (Jakarta: Rineka Citra, 1992), 69.

35 Herman Soewardi, Roda Berputar Dunia Bergulir: Kognisi Baru tentang Timbul Tenggelamnya Sivilisasi (Bandung: Bakti Mandiri, 2001), 22. 
Kalimantan Timur, pernah belajar di Pondok Pesantren Darussalam Gontor selama empat tahun lebih sembilan bulan. Karena keterbatasan ekonomi, Pak Kalend tidak bisa melanjutkan pendidikannya. Setelah mendengar ada seorang ulama yang disegani dan menguasai sembilan bahasa Asing yang tinggal di Dusun Singgahan, Pak Kalend memutuskan untuk belajar kepada KH. Ahmad Yazid, pengasuh Pondok Pesantren Darul Falah, sambil mendalami Bahasa Inggris. ${ }^{36}$ Ide untuk mendirikan tempat kursus Bahasa Inggris bermula dari kedatangan dua mahasiswa IAIN Surabaya yang ingin belajar Bahasa Inggris supaya lulus ujian di kampus. Berkat bantuan Pak Kalend, dua mahasiswa tersebut akahirnya berhasil lulus ujian. Dari sinilah, timbul kepercayaan diri untuk mendirikan lembaga kursus. ${ }^{37}$

Tahapan perubahan sosial di Kampung Inggris tidak hanya berhenti pada berdirinya satu lembaga kursus, akan tetapi terus berkembang dengan menjamurnya lembaga-lembaga serupa sampai Desa Tulungrejo dan Pelem. Berawal dari satu lembaga, akhirnya memberi efek kepada masyarakat untuk mendirikan lembaga-lembaga serupa. Hal ini dilatarbelakangi oleh banyaknya pendatang yang semakin mengenal Dusun Singgahan dan sekitarnya sebagai tempat kursus. Pada umumnya, lembaga kursus yang ada didirikan oleh alumni BEC yang memiliki kemampuan dan pemahaman lebih dalam bahasa asing.

Dengan banyaknya lembaga kursus, banyak terjadi perubahan Sosioreligius pada masyarakat di Kampung Inggris. Jumlah organisasi sosial yang awalnya hanya 11, yaitu: NU, Muhammadiyah, Muslimat, Wanita Islam, Kelompok Pengajian, Karang Taruna, Kelompok Tani, Kelompok Mina Jaya, Perkumpulan Pemilik-pemilik Kos, Forum ketua RT/RW, dan PKK telah bertambah dua; LDII dan HTI. Menurut Ali Sukron, kemunculan organisasi sosial baru yang membawa pemikiran dan ideologi yang beragam tidak dapat dipungkiri, akibat banyaknya pendatang dari berbagai daerah. ${ }^{38}$

Jika organisasi sosial tidak mengalami perubahan yang cukup signifikan, kegiatan organisasinya justru menunjukkan sebaliknya. Kegiatan-kegiatan kolektif masyarakat semakin berkurang, bahkan ronda yang semula ada, sekarang mulai ditinggalkan oleh warga di

\footnotetext{
${ }^{36}$ Kalend Oseng, Wawancara, Pare 22 Juni 2017.

${ }^{37}$ Ibid.

38 Ali Sukron, Wawancara, Pare 10 Agustus 2017.
} 
beberapa RT. Penurunan kegiatan kolektif tidak berlaku bagi organisasi Karang Taruna, tren wirausaha yang semakin meningkat akibat terbukanya peluang-peluang ekonomi baru di Kampung Inggris oleh sebab semakin banyaknya lembaga kursus dan pendatang di sana menyebabkan organisasi ini mengambil peran melakukan pendampingan dengan menggelar kegiatan pelatihan usaha. ${ }^{39}$ Selain berkurangnya kegiatan kolektif warga, dampak negatif lain yang timbul sebagai akibat interaksi dengan pendatang adalah imitasi yang berkembang ke arah negatif. Meskipun terjadi imitasi negatif perilaku siswa dan pendatang, karena keberadaan mereka yang hanya sementara, sugesti tokoh masyarakat setempat masih mampu mengurangi imitasi tersebut. Bukti dari sugenti ini adalah keikutsertaan masyarakat dalam kegiatan keagamaan dan adat istiadat yang masih intens. ${ }^{40}$

Kondisi ekonomi yang berkembang dan perubahan dari masyarakat agraris menuju masyarakat kapitalis yang terjadi di Kampung Inggris memengaruhi kondisi Sosioreligius di tempat tersebut. Ciri-ciri masyarakat kapitalis yang cenderung pragmatis, tidak mengindahkan struktur-fungsional keagamaan, dan berperilaku individualistik mulai menjangkiti sebagian masyarakat di Kampung Inggris. Orang-orang cenderung bersikap individualis. Kegiatan keagamaan terlihat kurang menarik karena masyarakat lebih disibukkan dengan kegiatan yang bersifat transaksional. ${ }^{41}$ Dampak negatif lain yang timbul akibat perubahan ekonomi adalah konflik antar warga yang memiliki kesamaan pekerjaan meskipun tidak terlalu mencolok. Konflik yang muncul seringkali bersifat personal dan terjadi secara sembunyi-sembunyi, tidak sampai diperlihatkan di permukaan. Namun demikian, secara umum mereka berusaha menghindari terjadinya konflik tersebut. Seperti yang dilakukan Mujiono, ia memilih berjualan barang yang belum ada di Kampung Inggris untuk menghindari persaingan antar sesama penjual yang memiliki kesamaan barang dagangan. ${ }^{42}$

Untuk memahami etos kerja masyarakat Kampung Inggris, terlebih dahulu harus memahami pola interaksi sosial masyarakat yang membentuk etos kerja mereka. Awalnya, interaksi masyarakat

39 Widodo (Ketua Paguyuban Pedagang Kampung Inggris), Wawancara, Pare 18 Februari 2016.

40 Ali Sukron, Wawancara, Pare 10 Agustus 2017.

${ }^{41}$ Mujiono, Wawancara, Pare 20 Februari 2017.

42 Jarot, Wawancara, Pare 18 Februari 2017. 
Kampung Inggris hanya berupa hubungan timbal balik untuk mencapai tujuan tertentu. Hal yang sama juga terjadi antara masyarakat dan pemilik lembaga. Pola interaksi yang terjalin di antara keduannya berdasarkan asas saling membutuhkan. Di awal berdirinya lembaga kursus, masyarakat Kampung Inggris belum bisa menerima sepenuhnya, masih merasa canggung dan meraba-raba seperti apa lembaga kursus tersebut. Namun dengan adanya beberapa tahapan perubahan, mereka sudah mulai menerima keberadaan lembaga tersebut.

Berdasarkan observasi yang dilakukan peneliti, interaksi sosial yang terjalin antara masyarakat dan pemilik lembaga sangat baik. Hal tersebut dibuktikan dengan adanya kegiatan reuni yang dilakukan oleh masyarakat dengan pemilik lembaga setiap hari raya. Tidak hanya itu, ketika masyarakat bermusyawarah untuk membahas Kampung Inggris, lembaga juga diikutsertakan dalam musyawarah tersebut. Selain itu, sebagian masyarakat mengetahui nama, tempat dan pemilik lembaga kursus di Kampung Inggris. Pemilik lembaga kursus pun juga sangat toleran dengan masyarakat sekitar, saling menghargai kepentingan masing-masing dan bisa bekerjasama dengan baik. ${ }^{43}$

Hubungan baik itu terjalin karena keduanya saling membutuhkan. Minimal, hal itu tercermin pada penerimaan masyarakat terhadap keberadaan lembaga kursus yang semakin menjamur. Masyarakat juga tidak keberatan dan mengizinkan wilayahnya dibanjiri pendatang dari luar. Bahkan, adanya lembaga kursus juga memberikan dampak positif bagi perkembangan dan perubahan masyarakat. Hubungan sosial yang sangat baik tersebut dilatarbelakangi oleh adanya sikap saling mengerti maksud dan tujuan masing-masing. Selain itu, karakteristik keagamaan warga Kampung Inggris juga mulai berubah. Mereka menyadari bahwa Islam tidak menempatkan perintah bekerja sebagai formalitas perintah agama. Lebih dari itu, bekerja dengan sungguh-sungguh merupakan salah satu bentuk implementasi keimanan dan ketaatan kepada Allah. Implikasinya, bekerja sungguh-sungguh akan memberikan dampak positif bagi kehidupan seorang muslim. ${ }^{44}$

Secara umum, masyarakat sangat menerima keberadaan pendatang yang ingin belajar di Kampung Inggris. Sebagian dari mereka sempat sedikit shock culture dengan kebiasaan para pendatang yang sering membuat gaduh, pulang malam, bermain musik sampai larut malam

\footnotetext{
43 Agus, Wawancara, Pare 18 Februari 2017.

44 Ali Sukron, Wawancara, Pare 10 Agustus 2017.
} 
dan bertengkar. Kebiasaan tersebut jauh dari dan tidak sesuai dengan nilai dan norma yang berlaku di masyarakat Kampung Inggris. ${ }^{45}$ Bahkan, sebagian lain beranggapan bahwa kampungnya sudah sangat rusuh dan tidak aman, sehingga dibentuklah Organisasi Mitra Kerja Masyarakat (OMKM) yang tujuannya menjaga keamanan dan ketertiban di Kampung Inggris. ${ }^{46}$ Awalnya, OMKM dibentuk atas ide dari masyarakat dan tokoh dengan melibatkan lembaga kursus untuk membuat peraturan bagi para pendatang. Tujuannya, menjaga kondisi Kampung Inggris agar bisa kembali stabil dan tidak rusuh. Karena itu, masyarakat beserta tokoh masyarakat sering mengadakan perkumpulan setiap bulan. Akan tetapi, setelah kondisinya kembali stabil dan ketenangan kembali normal, kegiatan perkumpulan hanya dilakukan satu tahun sekali. Tidak hanya itu, pola interaksi masyarakat kepada pendatang juga diejawantahkan dengan memberikan keamanan melalui kerjasama dengan pihak kepolisian.

Salah satu indikator dalam memenuhi etos kerja masyarakat di Kampung Inggris adalah efisiensi. Efisiensi patut dimiliki seseorang dalam bekerja untuk memenuhi kebutuhan yang ingin dicapai. Petani bukanlah pekerjaan yang mudah. Ia harus mencurahkan seluruh waktu, tenaga dan biaya sebagai modal aktivitas bertani yang yang berkorelasi dengan pencapaian hasil yang diinginkan. Pola pikir inefisiensi pertanian semacam ini telah ada dalam masyarakat. Karena hasil pertanian kurang memuaskan, akhirnya para petani lokal beralih menjadi pemilik modal atau melirik profesi lain yang lebih menguntungkan dari sisi ekonomi. Kondisi inilah yang menyebabkan peralihan dari masyarakat agraris menjadi kapitalis, dari pola keagamaan organis-religius menjadi mekanis-religius.

Ajaran Islam berpengaruh kuat terhadap sistem nilai yang ada dalam kebudayaan masyarakat Kampung Inggris. Secara langsung atau tidak, etos kerja yang menjadi pedoman eksistensi dan kegiatan yang ada dalam masyarakat dipengaruhi, digerakkan dan diarahkan oleh berbagai sistem nilai yang sumbernya dari agama Islam. ${ }^{47}$ Kegiatan

${ }^{45}$ Darul (Ketua RT 03 RW 02 Desa Pelem), Wawancara, Pare 2 Agustus 2017.

${ }^{46}$ Matsudi (Perangkat Desa Tulungrejo), Wawancara, Pare 2 Agustus 2017.

47 Agama dan etos kerja memiliki relevansi sangat signifikan sebagai salah satu motivasi semangat spiritual untuk mendapatkan nilai tambah kebaikan dan dapat dijadikan ladang amal. Karena hampir setiap agama mengajarkan bahwa diri kita sendiri lah yang akan bertanggungjawab atau menuai hasil dari pekerjaan yang dilakukan selama hidup. Jadi, meskipun manusia bebas memilih, tetapi harus 
ekonomi merupakan salah satu yang dipengaruhinya. Itulah sebabnya agama menjadi unsur non-ekonomi yang memengaruhi tingkah laku ekonomi, yang pada gilirannya akan melahirkan pola-pola tertentu dalam kegiatan ekonomi masyarakat. Menurut Kenneth E. Boulding, pengaruh agama terhadap kehidupan ekonomi sangat kuat sehingga turut memengaruhi jenis komoditi yang diproduksi, terbentuknya kelembagaan ekonomi dan praktik-praktik atau perilaku ekonomi. ${ }^{48}$

Perubahan ekonomi di Kampung Inggris didorong oleh beberapa faktor. ${ }^{49}$ Pertama, kebutuhan hidup yang terus meningkat. Semakin mahalnya bahan bakar minyak menyebabkan harga barang-barang juga meningkat karena ongkos pengiriman yang semakin mahal. Ini menyebabkan masyarakat beralih profesi untuk mendapatkan pemasukan lebih guna mencukupi kebutuhan hidup. ${ }^{50}$ Kedua, perubahan fisik manusia. Semakin bertambah umur seseorang, kondisi fisiknya pun berubah. Fisik yang tak lagi kuat dan tangguh juga menjadi penyebab berubahnya profesi seseorang. ${ }^{51}$ Ketiga, keinginan hidup yang lebih baik. Setiap orang pasti ingin hidup yang lebih baik. Namun demikian, tidak semua orang mau mewujudkannya melalui tindakan nyata. Mewujudkan keinginan melalui tindakan pun, bisa dilaksanakan sendiri atau direalisasikan oleh generasi penerusnya.

bertanggungjawab atas pilihannya sendiri dan inilah hal yang ditekankan dalam etika Protestan. Charles Kimball, Kala Agama Jadi Bencana (Jakarta: CRCS/Mizan Publika, 2008), 171.

48 Malcolm Brownlee, Tugas Manusia dalam Dunia Milik Tuban (Jakarta: BPK Gunung Mulia, 1987), 24.

${ }^{49}$ Kurniawan, "Pengaruh Keberadaan Kampung Inggris Terhadap Guna Lahan dan Sosial, 10-17.

50 Islam menghendaki setiap individu hidup di tengah masyarakat secara layak sebagai manusia, setidaknya dapat memenuhi kebutuhan pokok berupa sandang pangan, memperoleh pekerjaan sesuai dengan keahliannya, atau membina rumah tangga dengan bekal yang cukup. Untuk mewujudkannya, Islam mengajarkan setiap orang untuk bekerja dan berusaha, menyebar di muka bumi untuk mencari rejeki. Imām Bukhārī meriwayatkan bahwa Rasulullah bersabda yang artinya: Tidak ada satu makanan pun yang lebih baik dari makanan dari hasil kerja tangannya dan sesunggubnya Nabi Daud makan dari hasil kerja tangannya sendiri. Zainuddin Hamidy, et. al., Terjemah Hadist Shabih Bukhari (Jakarta: Widjaya, 1996), 129.

51 Tim Lajnah Pentashihan Mushaf al-Qur'an Badan Litbang dan Diklat Kementerian Agama RI, Kerja dan Ketenagakerjaan: Tafsir Al-Qur'an Tematik (Jakarta: Aku Bisa, 2012), 126. 
Sebab, setiap orang memiliki pemikiran bahwa generasi penerusnya harus lebih baik dan lebih berhasil daripada dirinya. ${ }^{52}$

Keberadaan lembaga-lembaga kursus di Kampung Inggris menjadi faktor pendorong utama warga untuk berwirausaha. Mereka melihat ada target pasar yang besar dengan adanya lembaga-lembaga kursus yang memiliki banyak murid dan investor-investor yang menyewa lahan untuk didirikan lembaga kursus. Toto Tasmara dalam bukunya Etos Kerja Pribadi Muslim menyebutkan, ciri etos kerja tinggi seorang muslim adalah memiliki semangat wiraswasta yang tinggi, memikirkan fenomena yang ada di sekitarnya, merenung dan semangat mewujudkan perenungannya dalam bentuk nyata. Dengan begitu, ia mengikuti jiwa wiraswasta Nabi Muhammad yang berdagang untuk mendapatkan penghasilan. ${ }^{53}$

Bruce J. Cohen menyebutkan bahwa perubahan sosial dipengaruhi oleh faktor geografis. Lingkungan fisik, yang berupa keadaan alam sekitar, dapat memengaruhi perubahan dalam masyarakat. ${ }^{54}$ Secara geografis, Kampung Inggris letaknya sangat strategis, karena berada di persimpangan jalan provinsi dan kabupaten menuju Kabupaten Jombang dan wilayah Malang. ${ }^{55}$ Kampung Inggris juga dekat dengan daerah wisata Simpang Lima Gumul, Gunung Kelud, Kota Batu serta Malang, sehingga ramai dilewati orang. ${ }^{56}$ Selain ramai, Kampung Inggris juga potensial untuk dikunjungi karena banyak pertokoan,

\footnotetext{
52 Nabi Muhammad menganjurkan seseorang untuk bekerja, meninggalkan rumah pada pagi hari untuk mencari nafkah. Bukan hanya pasrah, berpangku tangan, bermalas-malasan di tempat tinggal mengharapkan pemberian orang lain. Para sahabat pun juga mencontohkannya dengan gigih dan ulet berdagang lewat jalan darat dan laut. Mereka bekerja dan berusaha sesuai dengan kemampuan dan keahliannya masing-masing. Jika dijalankan sesuai ajaran Islam, kerja merupakan salah satu bentuk jihad yang tidak dapat dipisahkan dari signifikansi religius dan spiritualnya. Siti Muri'ah, Nilai-nilai Pendidikan Islam dan Wanita Karir (Semarang: Rasail Media Group, 2001), 135.

53 Menurut Hamka, Allah menyuruh manusia untuk bekerja menurut bakat dan bawaan, yaitu manusia diperintahkan untuk bekerja sesuai tenaga dan kemampuannya. Artinya manusia tidak perlu mengerjakan pekerjaan yang bukan pekerjaannya, supaya umur tidak habis percuma. Dengan demikian, manusia dianjurkan untuk tidak bermalas-malas dan menghabiskan waktu tanpa ada manfaat. Mutu pekerjaan harus ditingkatkan, dan selalu memohon petunjuk Allah. Hamka, Tafsir al-Azhar, Vol. 28 (Jakarta: Pustaka Panjimas, 1985), 39.

${ }^{54}$ David C. Mcclelland, The Achieving Society (D van Nostrand Coy Co.: Inc. New Jersey, 1961), 71.

${ }_{55}$ Data Kampung Inggris, Desember 2017.

56 Ar Rahman Taufik Hidayat, "Pengaruh Keberadaan Kampung Inggris", 15.
} 
lembaga pendidikan dan pasar besar. Karena itu, pertukaran nilai dan norma antar warga sangat mungkin terjadi. Melalui pertukaran inilah potensi perubahan bisa terjadi.

Faktor yang lain adalah kepimpinan. Perubahan sosial juga sering dimulai oleh pemimpin yang kharismatik. Pemimpin ini dapat direpresentasikan oleh pemimpin organisasi di desa maupun pemimpin rumah tangga. Pemimpin organisasi yang kreatif dan kharismatik dapat membuat organisasi maju, seperti Kalend yang disegani oleh masyarakat Kampung Inggris dan menjadi inisiator berdirinya Kampung Inggris.

Adanya korelasi antara nilai-nilai agama Islam dengan etos kerja mengindikasikan bahwa kemudahan-kemudahan hidup masyarakat Kampung Inggris merupakan jawaban dari keuletan kerja mereka. Agama bagi mereka merupakan petunjuk hidup, arahan dan pegangan menuju kebahagiaan hidup di dunia dan akhirat. ${ }^{57}$ Bagi Calvin, seperti ditulis Weber, etos kerja harus dimulai dengan kesadaran akan pentingnya arti tanggung jawab kepada masa depan bangsa dan negara. Dorongan untuk mengatasi kemiskinan, kebodohan dan keterbelakangan hanya mungkin timbul jika seluruh masyarakat memiliki orientasi kehidupan masa depan yang lebih baik. ${ }^{58}$

Apa yang dilakukan masyarakat Kampung Inggris ini sama dengan etos kerja kalangan Calvinis dalam menumbuhkan kapitalisme di Eropa. Bagi Calvin, pekerjaan adalah rahmat Tuhan yang dilimpahkan kepada manusia, melayani merupakan wujud syukur seseorang kepada Tuhan. Menjalankan peran dengan penuh keikhlasan merupakan kunci etos kerja profesional. Seseorang yang mendapat amanah Tuhan harus ikhlas menerima peran dan melayani tanpa pamrih. Aktualsisasi keikhlasan tersebut berupa menyikapi pekerjaan sebagai skenario Tuhan, karena pekerjaan itu suci. Karenanya, harus dilakukan dengan kesucian dan semata-mata untuk Tuhan. Pekerjaan yang dicintai, dijalani dengan sebaik-baiknya akan mendatangkan manfaat yang lebih besar, tidak hanya bagi pelaku namun juga masyaarakat. ${ }^{59}$

Kehadiran BEC sampai terbentuk Kampung Inggris tahun 2001 bagi masyarakat Kampung Inggris memberi berkah tersendiri. Karena selain menjadi lokasi memperdalam bahasa asing, juga menjadi karya

\footnotetext{
${ }^{57}$ Kalend, Wawancara, Pare 12 Agustus 2017.

${ }^{58}$ Max Weber, The Protestant Ethic and The Spirit of Capitalism (New York: Charles Scribners Sons, 1958), 23.

59 Abraham Kuyper, Ceramah-ceramah Mengenai Calvinisme, terj. Peter Suwadi Wong (Surabaya: Penerbit Momentum, 2012), 14.
} 
besar yang dinikmati oleh masyarakat. Ini merupakan manifestasi kesadaran masyarakat Kampung Inggris sebagai khalifah di dunia. Bagi mereka, manusia sebagai wakil Tuhan, bertanggungjawab untuk menjaga dan memanfaatkan bumi bagi kemaslahatan seluruh makhluk. Konsekuensinya, tanggungjawab ini harus diwujudkan dalam kerja keras. Bagi seorang muslim, kerja adalah ibadah, bukti pengabdian dan rasa syukur untuk mengolah dan memenuhi panggilan Ilahi untuk menjadi yang terbaik. Mereka sadar bahwa bumi merupakan ujian bagi mereka yang memiliki etos terbaik. Karena itu, kerja dalam perspektif Islam bisa dimaknai sebagai penjabaran dari akidah, perwujudan masa depan, pertumbuhan, keuletan, dan peluang. ${ }^{60}$

Kepercayaan umat Muslim Kampung Inggris kepada kehidupan akhirat dapat menimbulkan sikap tanggungjawab. Kepercayaan tehadap balasan, pahala, dosa dan sebagainya memotivasi masyarakat untuk berbuat baik, termasuk dalam urusan bekerja. ${ }^{61}$ Paham zubd atau hidup sederhana juga memiliki makna dan peran tersendiri. Bagi enterpreneur tradisional, paham semacam ini melahirkan sikap hemat sehingga bisa mempunyai tabungan investasi. Di samping itu, sikap jujur juga punya andil. Jujur melahirkan etos mempertahankan kualitas produk. Salah satu etos kerja islami lainnya adalah hidup hemat. Hemat bukan karena ingin menumpuk kekayaan dan melahirkan sifat kikir individualistik, tetapi karena ada satu reserve tidak selamanya waktu berjalan lurus. Adakalanya up and down, sehingga hemat berarti mengestimasikan apa yang akan terjadi di masa mendatang. Melakukan segala sesuatu secara benar dalam hidupnya adalah bentuk orang beretos kerja tinggi dan berpandangan jauh ke depan.

60 Toto Tasmara, Etos Kerja Pribadi Muslim (Yogyakarta: Dana Bhakti Prima Yasa, 1995), 22.

${ }^{61}$ Fungsi etos kerja bagi seorang pekerja sama seperti nafsu bagi seseorang. Nafsu oleh sementara ahli dimaknai sebagai potensi ruhaniah yang berfungsi mendorong seseorang untuk melakukan atau tidak melakukan sesuatu. Dengan demikian, perbuatan apapun yang dilakukan seseorang, baik terpuji maupun tercela adalah dorongan nafsu, sehingga posisi nafsu, begitu pula etos, adalah netral. Sementara, etos maupun nafsu sangat dipengaruhi oleh motivasi. Karena itu, bekerja seharusnya bukan sekadar aktivitas untuk menghasilkan sesuatu, akan tetapi harus diyakini sebagai bentuk pengabdian kepada Tuhan. Dengan kata lain, bekerja adalah ibadah. Sehingga jika seseorang berniat ibadah dalam bekerja, seharusnya juga menyadari bahwa etos kerja yang tinggi tidak selalu berbanding lurus dengan hasil atau keuntungan yang besar. Kenneth E Boulding dalam Dawam Rahardjo, Etika Ekonomi dan Manajemen (Yogyakarta: Tiara Wacana, 1990), 27. 


\section{Catatan Akhir}

Keberadaan lembaga-lembaga kursus Bahasa Inggris berpengaruh besar terhadap kehidupan sosial dan ekonomi masyarakat. Struktur ekonomi yang semula agraris berubah menjadi kapitalis yang juga mengubah cara pandang keberagamaan masyarakat, dari yang awalnya organis-religius menjadi mekanis-religius. Dengan kata lain, kesadaran masyarakat melaksanakan nilai-nilai keagamaan yang mula-mula didorong oleh kebutuhan bermasyarakat sebagai bentuk ketergantungan pada lingkungan sosial yang diikat oleh norma-norma keagamaan tradisional, berubah menjadi kesadaran keberagamaan akibat perubahan struktur masyarakat yang dipengaruhi oleh perubahan struktur ekonomi. Pola interaksi sosial pun bergeser, dari kebutuhan menjadi keharusan. Peningkatan ekonomi masyarakat, selain memengaruhi rasionalitas keberagamaan juga berimbas pada fluktuasi jumlah penduduk yang menyebabkan timbulnya perubahan sosial keagamaan. Perubahan mata pencaharian dari agraris menuju non-agraris ikut merubah pola keberagamaan masyarakat Kampung Inggris.

Adanya korelasi antara nilai-nilai Islam dan etos kerja mengindikasikan bahwa bekerja bagi masyarakat Kampung Inggris merupakan keniscayaan dan bentuk jawaban atas kemudahankemudahan hidup. Agama bagi mereka merupakan petunjuk hidup, arahan dan pegangan menuju kebahagiaan di dunia dan akhirat. Kehadiran BEC hingga terbentuk Kampung Inggris memberi berkah tersendiri bagi masyarakat karena merupakan manifestasi dari kesadaran masyarakat sebagai khalifah di dunia. Bagi mereka, manusia memikul tanggungjawab sebagai wakil Tuhan dalam menjaga dan memanfaatkan bumi untuk kemaslahatan seluruh makhluk. Konsekuensi dari tanggungjawab ini harus diwujudkan dalam etos kerja yang tinggi, jujur dan hemat.

\section{Daftar Rujukan}

Agus. Wawancara. Pare 18 Februari 2017.

Amrullah. Wawancara. Pare 20 Juli 2017.

----. Wawancara. Pare 22 Juli 2017

----. Wawancara. Pare 27 Juli 2017.

Boulding, Kenneth E. dalam Dawam Rahardjo, Etika Ekonomi dan Manajemen. Yogyakarta: Tiara Wacana, 1990. 
Brownlee, Malcolm. Tugas Manusia dalam Dunia Milik Tuban. Jakarta: BPK Gunung Mulia, 1987.

Dagun, Save M. Sosio Ekonomi Analisis: Eksistensi Kapitalisme dan Sosialisme. Jakarta: Rineka Citra, 1992.

Darul (Ketua RT 03 RW 02 Desa Pelem). Wawancara. Pare 2 Agustus 2017.

Data Kampung Inggris, Desember 2017.

Hamidy, Zainuddin et. al. Terjemah Hadist Shahih Bukhari. Jakarta: Widjaya, 1996.

Hamka. Tafsir al-Azhar, Vol. 28. Jakarta: Pustaka Panjimas, 1985.

Harbison, Frederick dan Myers, Charles A. Manpower and Education:

Country Studies in Economic Development. New York: McGraw-Hill Book Company, 1965.

Jarot. Wawancara. Pare 18 Februari 2017.

John, Asmo. Wawancara. Pare 22 Juli 2017.

Karti. Wawancara. Pare 20 Juli 2017.

Kimball, Charles. Kala Agama Jadi Bencana. Jakarta: CRCS/Mizan Publika, 2008.

Kuyper, Abraham. Ceramah-ceramah Mengenai Calvinisme, terj. Peter Suwadi Wong. Surabaya: Penerbit Momentum, 2012.

Lubis, M. Ridwan. Agama dan Pembangunan Negara. Jakarta: Badan Litbang dan Diklat Kementerian Agama RI, 2015.

Matsudi (Perangkat Desa Tulungrejo). Wawancara. Pare 2 Agustus 2017

Mcclelland, David C. The Achieving Society. D van Nostrand Coy Co.: Inc. New Jersey, 1961.

Mubyarto. Reformasi Sistem Ekonomi: Dari Kapitalisme menuju Ekonomi Kerakyatan. Jakarta: Aditya Media, 1999.

Mujiono. Wawancara. Pare 20 Februari 2017.

Muri'ah, Siti. Nilai-nilai Pendidikan Islam dan Wanita Karir. Semarang: Rasail Media Group, 2001.

Observasi Kampung Inggris, 12 Agustus 2017.

Oseng, Kalend (Pendiri BEC Pare). Wawancara. Pare 20 Juli 2017.

----. Wawancara. Pare 12 Agustus 2017.

----. Wawancara. Pare 22 Juni 2017.

Poloma, Margaret M. Sosiologi Kontemporer. Jakarta: Rajawali Pers bekerja sama dengan Yayasan Solidaritas Gadjah Mada, 1992. 
Remmling, Gunter W. and Campbell, Robert B. Basic Sociology: an Introduction to the Study of Society. New Jersey: Littlefield, Adams dan Co, 1976.

Robertson, Roland. Agama: Dalam Analisa dan Interpretasi Sosiologi, terj. Achmad Fedyani Saifuddin. Jakarta: Rajawali, 1988.

Romlah. Wawancara. Pare 21 Juli 2017.

Siahaan, Hotman M. Pengantar ke Arah Sejarah dan Teori Sosiologi. Jakarta: Erlangga, 1986.

Soekamto, Soerjono. Pengantar Kesejahteraan Sosial. Jakarta: Gramedia, 2000.

Soewardi, Herman. Roda Berputar Dunia Bergulir: Kognisi Baru tentang Timbul Tenggelamnya Sivilisasi. Bandung: Bakti Mandiri, 2001.

Sukron, Ali (Kepala Desa Pelem). Wawancara. Pare 10 Agustus 2017.

Sumber data: Pusat informasi Kampung Inggris Pare tahun 2017.

Sumber data: Pusat Informasi Kampung Inggris tahun 2015.

Sumber data: Pusat Informasi Kampung Inggris tahun 2017.

Sumber: Tingkat penghasilan penduduk Dusun Singgahan tahun 2014.

Supriyadi R., Ery. Peran Universitas dalam Pengembangan Ekonomi Lokal: Kasus Kawasan Pendidikan Tinggi Jatinangor. Bandung: t.tp., 2012.

Tasmara, Toto. Etos Kerja Pribadi Muslim. Yogyakarta: Dana Bhakti Prima Yasa, 1995.

Tilaar, T.A.M. "Peran Perguruan Tinggi di Daerah Dalam Otonomi Daerah", dalam Pendidikan Untuk Masyarakat Indonesia Baru: 70 Tabun Prof. Dr. H.A.R. Tilaar, M.Sc. Jakarta: Grasindo, 2002.

Tim Lajnah Pentashihan Mushaf al-Qur'an Badan Litbang dan Diklat

Kementerian Agama RI, Kerja dan Ketenagakerjaan: Tafsir Al-Qur'an

Tematik. Jakarta: Aku Bisa, 2012.

Wagiran. Wawancara. Pare 20 Agustus 2017.

Weber, Max. Etika Protestan dan Semangat Kapitalisme. Yogyakarta: Narasi Pustaka Promethea, 2015.

-----. The Protestant Ethic and The Spirit of Capitalism. New York: Charles Scribners Sons, 1958.

Widodo (Ketua Paguyuban Pedagang Kampung Inggris). Wawancara. Pare 18 Februari 2016.

Wuryani, Ani. Wawancara. Pare 20 Juli 2017. 